\title{
Education Component in Creation of Entrepreneurship Society
}

\begin{abstract}
Entrepreneurship as a style and way of thinking and working has century's long history in the human society. Thanks to creative and open-minded people in the past and today, the human societies ensured rapid growth and improved the living standards. Innovative ideas triggered higher level of economic development in the world through new technologies, which has led to improving the quality of life. Unfortunately, not all countries in the world enjoy the same social progress, due to many problems in the areas of economic and political domain, access to natural and human resources, demographic issues, low level of education, etc.

The history of economics has shown that in the countries with open market economy, the entrepreneurial spirit is developed on the higher level. The entrepreneurial culture provides many opportunities for implementation of more innovative business ideas, new technical solutions, advanced technologies, new working methods and continued life-long education aimed to improve the life of the society.

Creative people and their ideas are crucial for the development and cultivation of the entrepreneurial spirit and culture in every country, which is closely connected to the education level gained through the formal and informal education systems, which depend of the country's economic development. A good education system plays an important role in creating good economic policies in each country, has influence on the economic development, business performance and the progress of the whole human society. Innovation is a unique path to prosperity and well-being. Therefore, the economic scientists recognize entrepreneurship as a dynamic factor of production, in addition to labor, capital and land.

The European Union (EU) recognizes and promotes many strategies and polices that focus on teaching entrepreneurship from early ages, starting within primary and secondary education, and continuing at the university levels. Developing new education curriculum in formal and informal education systems is a priority in the government's policies of the developed countries. The curriculum might include compulsory courses in entrepreneurship, continuous learning, and tailored courses
\end{abstract}

* Faculty of Social Sciences (FON), University of Skopje, R. Macedonia. 
with specific task to teach people how to be creative and innovative, regardless of their cultural differences and traditions.

Universities should play an important role in educating young people how to do business to work and succeed in the global market economy. The universities in many developed countries such as the USA, Japan, and Germany, have opened business centers, supported technological incubators and parks, and established specialized agencies that provide help and support to entrepreneurs. All these activities contribute to the development of the entrepreneurial society, where creative people can easily find their place for business and life. Thus, education is one of the key factors of economic development.

The knowledge-based economy is a modern economy that makes the goal of many countries of today's world. The less developed states should strive towards the modern trends in the education processes as well as business and entrepreneurial behavior, which is the critical factor in the development of economic and social welfare. They should make more efforts to support the business environment through progressive and modern education systems that would facilitate the development of entrepreneurial spirit and culture. Additionally, they should follow the new trends in the global economy that lead to social cohesion and better economic prosperity.

Keywords: entrepreneurship, entrepreneurial spirit, entrepreneurial culture, education, Life Long Learning (LLL).

\title{
Element edukacji w tworzeniu społeczeństwa opartego na przedsiębiorczości
}

\begin{abstract}
Abstrakt
Przedsiębiorczość jako styl oraz sposób myślenia i pracy jest obecna w naszym społeczeństwie od stu lat. Dzięki kreatywnym ludziom o otwartych umysłach, żyjącym w przeszłości i obecnie nastąpił szybki rozwój i poprawa warunków ludzkiego życia. Innowacyjne pomysły wprowadziły świat na wyższy poziom rozwoju gospodarczego za pomocą nowych technologii, które przynoszą poprawę jakości życia. Niestety, nie wszystkie kraje na świecie cieszą się takim samym poziomem postępu społecznego z powodu licznych problemów występujących w obszarach gospodarczych i politycznych, obejmujących między innymi dostęp do zasobów naturalnych i ludzkich, problemy demograficzne, niski poziom wykształcenia itp.

Historia ekonomii pokazuje, że w krajach o otwartej gospodarce rynkowej duch przedsiębiorczości jest rozwijany na wyższym poziomie. Kultura przedsiębiorczości daje wiele możliwości wdrażania bardziej innowacyjnych pomysłów biznesowych, nowych rozwiązań technicznych, zaawansowanych technologii, nowych metod pracy oraz edukacji przez całe życie, których celem jest poprawa życia społeczeństwa.

Kreatywni ludzie i ich pomysły to elementy kluczowe dla rozwoju i kultywowania ducha oraz kultury przedsiębiorczości w każdym kraju, co ma ścisły związek z poziomem wykształcenia zdobytego za pośrednictwem formalnych i nieformalnych systemów edukacji, które są uzależnione od rozwoju gospodarczego kraju. Dobry system edukacji odgrywa ważną rolę w tworzeniu dobrej polityki gospodarczej
\end{abstract}


w poszczególnych krajach, ma wpływ na rozwój gospodarczy i wydajność przedsiębiorstw, a także na postęp całego społeczeństwa. Innowacja to unikalna droga do dobrobytu. Dlatego też badacze zajmujący się ekonomią uznają przedsiębiorczość za kolejny dynamiczny czynnik produkcji, oprócz pracy, kapitału i ziemi.

Unia Europejska (UE) uznaje i wspiera wiele strategii i polityk, które skupiają się na nauczaniu przedsiębiorczości od wczesnego wieku, począwszy od szkół podstawowych i średnich, a kontynuując na poziomie szkolnictwa wyższego. Opracowywanie nowych programów kształcenia w formalnych i nieformalnych systemach edukacji to priorytet polityki rządowej w krajach rozwiniętych. Takie programy mogą obejmować przedmioty obowiązkowe z zakresu przedsiębiorczości, formy kształcenia ustawicznego, specjalnie przygotowane kursy uczące ludzi kreatywności i innowacyjności, niezależnie od dzielących ich różnic kulturowych i tradycji.

Uniwersytety powinny odgrywać istotną rolę w kształceniu młodych ludzi w zakresie prowadzenia firm oraz przygotowywać ich do funkcjonowania i odnoszenia sukcesów w globalnej gospodarce rynkowej. Uczelnie w wielu krajach rozwiniętych, takich jak USA, Japonia i Niemcy, otwierają centra biznesowe, wspierają inkubatory i parki technologiczne i zakładają specjalistyczne agencje zapewniające pomoc i wsparcie dla przedsiębiorców. Wszystkie te działania przyczyniają się do rozwoju społeczeństwa przedsiębiorczego, w którym kreatywni ludzie mogą bez trudu znaleźć swoje miejsce do życia i prowadzenia biznesu. Edukacja jest jednym z kluczowych czynników rozwoju gospodarczego.

Gospodarka oparta na wiedzy to nowoczesna gospodarka, która jest celem wielu państw dzisiejszego świata. Kraje słabiej rozwinięte powinny dążyć do wdrażania współczesnych trendów w procesach edukacyjnych oraz zachowaniach biznesowych, ponieważ jest to kluczowy czynnik rozwoju gospodarczego i społecznego dobrostanu. Powinny również wspierać środowisko biznesowe poprzez stopniowe wdrażanie nowoczesnego systemu edukacji, który będzie zgodny z duchem i kulturą przedsiębiorczości. Jednocześnie, powinny postępować zgodnie z nowymi trendami w gospodarce światowej, które prowadzą do spójności społecznej i lepszej koniunktury gospodarczej.

Słowa kluczowe: przedsiębiorczość, duch przedsiębiorczości, kultura przedsiębiorczości, edukacja, uczenie się przez całe życie.

\section{Introduction}

The modern world of globalization processes and high application of new technology as an imperative for human progress needs new goals, methods and tools in business activities, new knowledge and business ethics. It means the necessity of new culture of education in social and economic activities.

The universities play an important role of establishing the new, entrepreneurial society that means new curriculums, new educative and business centers, 
laboratories, business incubators, technological parks etc., which lead to the creation, innovative processes, as sine qua non for modern working and life.

It is widely widespread understanding and recognition that entrepreneurship is a driving force of the national economy and the society. Entrepreneurship provides parallel positive impulses of social and individual level, through personal achievement and job satisfaction, which reflects the rapid and sustainable growth and development. With the development of entrepreneurship strengthen the interest and the need for proper education in order to increase the competence and expertise of entrepreneurs, to encourage new business and creativity. Only knowledge makes people brave and encourages starting work, creating new values to be successful and valued members in their community. New knowledge is the necessary and important for existing businesses to grow faster and to be present in global markets.

\section{Entrepreneurial Education}

Education system generally leads to the better understanding of the new processes in the nature, in the society in the world and place where we live and work. New skills and knowledge are capabilities for more creative activities, for innovation as key factor for new and modern economic activities, for elimination of ethnic differences and poverty, for elimination of cultural differences and different religion groups, for better living. Modern education system means new curriculums, new knowledge of creation of modern technology and new methods of running businesses, acceptance of information technology and entrepreneurial education as a part of modern style of working and living.

The European Union has accepted a lot of documents for creation of competitive environment for business. Many of them refer to lifelong learning (LLL) as a key factor for successful economic prosperity.

\section{The European Union}

EU Commission ${ }^{1}$, in order to make the EU a leading and growing economy, has adopted and implemented many documents that highlight the priorities in development. They stressed the need to strengthen the knowledge-based economy, the competitive production, application of new technologies and knowledge gained by increasing the role of formal education, informal education and lifelong learning. Significant strengthening of the entrepreneurial spirit of the population from an early age for EU authorities has primary place.

\footnotetext{
${ }^{1}$ Entrepreneurial Learning, A Key Competence Approach, ISCED-level2,South-East European Centre for Entrepreneurial Learning, Brussels.
} 
First Lisbon Strategy of 2000, then the European Charter for Small Enterprises (adopted in 2000 and passed in 2002 and 2003) in which education and training for entrepreneurship as a basic knowledge for running businesses and strengthening the entrepreneurial spirit.

Also, the Green Paper on Entrepreneurship in the EU (2003) $)^{2}$ emphasized that "education and training should contribute to encouraging entrepreneurship; developing awareness and thinking (mentality) that can make a successful career as an entrepreneur with possession of knowledge and skills".

In 2006, the EU prepared a document titled European Framework for Key Competences for Lifelong Learning ${ }^{3}$, which is accepted by all member states and candidate. The main objective of the paper is the development of entrepreneurial literacy as a condition for a competitive economy by providing sustainable economic growth and development.

For additional competencies / skills are outstanding:

- Ability to communication / language of communication,

- Ability to communication / communication in foreign languages,

- Math skills and basic knowledge and skills of science and technology,

- Digital-abilities,

- Learning how to learn,

- Social and civic competences,

- Sense of initiative and entrepreneurship,

- Awareness of culture and expression.

Awareness of the need for entrepreneurial learning in the EU continues to evolve, especially with the adoption of the Oslo Agenda for Entrepreneurship Learning in Europe ${ }^{4}$, which are directed educational institutions to introduce curriculum with entrepreneurial education as early as elementary school. These suggestions aim to develop awareness of each pupil and student that should have entrepreneurship competences. It is a key competence that everyone needs to develop and there, whether in the future will become an entrepreneur and businessman or something else. It means way of thinking should be an integral part of every program in all areas of studies.

European Framework for Qualifications contains multiple components that indicate a clear provision for the development of national qualifications system integration of entrepreneurial learning as a key capability for every citizen.

EU has adopted several documents on lifelong learning (LLL) or permanent education task for all people of every level of age to stimulate the learning process and to develop the sector of education and training in countries all over Europe. Program contains four sub-programs for school children, students, adults, teachers and trainers, as well as exchanges between their countries.

\footnotetext{
2 Green Paper for Entrepreneurship in EU (2003), Brussels.

${ }^{3}$ European Framework for Key Competences for Life Long Learning (2006), Brussels.

${ }^{4}$ European Commission: Oslo Agenda for Entrepreneurial Education in Europe, October 2006, Oslo.
} 
Notably Comenius program for schools, Erasmus for higher education, vocational education and training Leonardo da Vinci, and the adult education program is designed Grundtvig.

In Macedonia the Law on Civil outstanding universities in lifelong learning is adopted 5 .

Lifelong learning or permanent education is especially important for business people considering permanent need of refreshment and improvement of the relevant knowledge for getting new, according to the needs of modern business and working requirements imposed by the globalization of the world economy.

Only the best succeed on the global market, the harsh realities of global markets require new knowledge and skills to survive. Hence the efforts of the EU are for permanent education, entrepreneurial learning, the development of consciousness and the mentality of the population. Entrepreneurial mind, spirit and culture are necessary as a manner of life in the interest of their individual development, but also for the development of a wider community and society.

The European Commission, together with the Organization for Economic Cooperation and Development (OECD), is launching a new online self-assessment tool for universities to measure how entrepreneurial they are $^{6}$.

Under each of the seven assessment areas, the institutions are invited to score themselves from 0-10 in response to statements such as:

- Entrepreneurship is a major part of the university strategy;

- The university is open to recruiting and engaging with individuals who have entrepreneurial attitudes, behaviors and experience;

- The university validates entrepreneurship learning outcomes;

- Business start-up education is offered across the curricula and faculties;

- The university facilitates access to private financing for its potential entrepreneurs;

- The university has strong links with incubators and science parks.

The website then generates results for the institution, highlighting areas of strength and weakness. It also helps the institution improve its performance by providing links to customized examples of good practice.

Entrepreneurship and innovation Programme (EIP), adopted by European Commission in 2014 (March, 31) ${ }^{7}$ is focused in these topics:

- Access to the Finance,

- Support to Innovation,

- Support to Eco-innovation,

- Business and Innovation Services,

- Promotion of Entrepreneurship.

\footnotetext{
${ }^{5}$ Official Gazette, 36/2011, Brussels.

${ }_{6}$ Commission and OECD launch website for universities to measure entrepreneurial impact (IP/13/1093).

${ }^{7}$ EE/EU, Official Gazette March/2014.
} 
The document shows the intention of the Economic Commission for permanent promotion of entrepreneurship as a key factor for fast economic growth and prosperity of the society. Promotion of entrepreneurship include contemporary education component in entire process of raising the entrepreneurial culture and spirit of creation new goods and prosperity as an aim in the every society.

Modern education system includes experts from different countries to change the experience, new curriculums with modern trend in economy, running businesses, new technology and knowledge. Life Long Learning (LLL) is tool for gather life experience and new knowledge and skills for better running the business activities.

\section{Entrepreneurial Tertiary Education in the Republic of Macedonia}

Realizing the importance of the need for entrepreneurial learning as an important factor in the formation of educated and trained people for run the business in a modern way, is adopted a Declaration of the Promotion of Entrepreneurial Learning, in June 20098, which contains the following goals and activities to be reached:

- Innovation and entrepreneurship are the basis for increasing the country's competitiveness,

- Entrepreneurs are the engine for the market economy,

- Entrepreneurship is growIng into one of the key competences for lifelong learning,

- Universities are key drivers of economic development,

- Education based on competencies play a central role in our society,

- Stimulation of high education institution / universities to develop entrepreneurial abilities through:

- introduction of courses of entrepreneurship and the development of appropriate curriculum, methods;

- ensure availability of resources (access to training materials) for students of all faculties;

- training of teachers for entrepreneurship;

- opening of entrepreneurship centers;

- strengthening of relations with the industry and common / joint projects;

- sharing of best practices within the university and with other universities.

The Declaration complete has accepted the recommendations and guidelines for the development of entrepreneurial learning, provided by the European Commission and the European Training Foundation (ETF) in Turin, Italy.

${ }^{8}$ Official Gazette: June/2009, Macedonia. 
The Declaration emphasized the needs of:

- promotion of entrepreneurial learning and favorable business environment for encouraging entrepreneurship and self-employment;

- development of national policy for high education, which will be in the function of Entrepreneurial Learning;

- stimulation of high education institution / universities in that direction.

The declaration would be realized through the Ministry of Economy and Ministry of Education.

Practice shows progress in the field of entrepreneurial learning, although awareness of the population slowly changing. However, with the introduction of the curriculum in secondary schools and in universities, with trainings etc., the country is making progress in this area.

Well known large companies have their own training centers for management and entrepreneurial skills, for its employees, but also for students, unemployed and interested citizens.

The future is in getting new knowledge, to create knowledge based economy, with competences for innovation and implementation of new technology to face people into difficult problems and challenges. This creates an entrepreneurial society in which all creative and inventive people find their place in businesses, research and development (R\&D) and creation of new values, which strengthen the economy, and lead to prosperity and social welfare.

\section{The Universities' Function in Raising the Entrepreneurial Spirit and Culture}

University as an educative institution is a cradle of education, of new knowledge, new technology, research and development (R\&D) as well as a place that provides entrepreneurial skills and upbringing young people.

The modern university, in terms of globalization of economic life, is necessary quickly and effectively to adapts to the needs of the economy and young people, and provides the new knowledge for managers, entrepreneurs ${ }^{9}$, employees, prospective entrepreneurs. Nowadays, we talk about the third generation of the University (Wisema 2008), which suggests cooperation with the industry through joint projects and assistance in running businesses, R\&D, education and permanent education of owners, managers, entrepreneurs, employees. Modern universities should raise the spirit of entrepreneurship of the students, their creative ideas for business activities and innovation.

\footnotetext{
9 The University Business Forum, a trends report 2006-2011, January 2012, Danish Technological Institute, Techno polis group.
} 
The role of the university would be realized through the following issues:

A) The curriculum of modern universities must be in the spirit of the new trends in the world economy, the spirit of entrepreneurial learning and new knowledge and technologies in order future business people and their companies to be viable in world markets, to raise its competitive ability. The universities should be prepared in order to meet the future needs of businesses and entrepreneurs.

B) Today, in the most developed countries, the universities have special business centers, agencies for entrepreneurs' help and support in running their businesses, making market and business plans and strategies, export promotion, business information, internationalizations etc. At the same time, from the modern universities is expected to be connected to industrial enterprises and their help in the form of expertise, joint projects, using new technological innovation. Research and development (R\&D), modern laboratories as well are very significant for positive role of the universities for economic development.

C) Current economic trends require entrepreneurs to be educated, prepared and armed with the latest new knowledge and developed skills to successfully run their organizations. The role of universities in this domain is especially great in organization of courses, seminars, trainings, studies and various forms of lifelong learning for business people. In Europe, managers attend training 1-4 weeks annually, employees at least once minimum.

D) The Universities in developed countries have an active partnership and collaboration with the public and private sector, large enterprises and universities, national and local authorities. The results are very positive.

The famous models of the development of entrepreneurship and SMEs are based on strong role of the universities and entrepreneurs, the association of businessmen and local authorities, common realization of some project and joint venture. The third generation of the universities means close cooperation between the business community and science. In these processes permanent education of the employees is obliged in purpose for acceptance of new knowledge and skills.

\section{Some Examples of the Universities that play an important Role in the Development of Entrepreneurship}

In the U.S.A. is well known model of development in Pittsburgh. Namely, during the eighties of the 20th century, when the steel industry crisis hits, the city authorities found a solution for restructuring economy through the support and development of small businesses, with the help of the universities. With its professional and scientific human resources, universities organize the entrepreneurial incubators and technology parks, in which unemployed and laid-off workers were able to make qualification and skills for run new businesses. The new knowledge obtained 
from the Universities allowed the local enterprises to apply new technologies and methods of work, to help development of creativity of individuals. Today, Pittsburgh is a symbol of a modern city, with widely applied high technology and small enterprises.

In each of the universities in the U.S.A., there are business centers (for example John Mason University in Washington) that help local entrepreneurs with advises, making plans, strategies etc. in the field of running business and start up. These centers serve the needs of business people preparing business plans, business strategies, and plans for activities in the field of marketing, management, export promotion, quality standards etc. Thus, modern knowledge becomes closer to businessmen or science finds its practical application in the industry and economy.

Faculty of Economics at University of Ljubljana, the Republic of Slovenia, has the Center for Entrepreneurship that works very successfully. Such centers exist in most universities in economically developed countries, but also in less developed countries, where the authorities have understood the role of entrepreneurship in the overall socio-economic development.

Well known is partnership with University from Bologna and local community in process of economic development of Emilia Romagna Region in Italy that is one of the 10 most developed regions in the EU. The development of the Region is characterized by the cooperation of national, regional and local authorities with private sector and Bologna University. It provides establishment of the ERVET network that provide a lot of services for the enterprises. In economic literature this example is well known as a model of competitiveness (Porter 1990) of ceramic industry and model of small business development, thankful on the common actions of all relevant institutions and private sector on local level with support of national authorities and institutions.

In Berlin, Germany is well known technological park, which is a result of cooperation between the "Humboldt" University and "SIMENS". There are developing new and innovative startup companies that develop high technology.

In highly developed countries, all universities have centers, agencies, and departments to help entrepreneurs, training centers, career centers and bodies that are aimed to help prospective and existing business people. It creates entrepreneurial society that means people with entrepreneurial spirit and culture; there have awareness for entrepreneurial mind and behavior. The EU countries as well as other high developed countries, like USA, Japan have many magnificent events, institution and "best practices" in promotion activities and support of entrepreneurship learning and developing the entrepreneurship spirit that leads to the creative people and prosperity of the country.

It should be the good example for less developed counties and society, like Macedonia and others for fostering spirit and culture for creation, innovation as a main factor for economic development and prosperity. In these processes, modern education systems play a significant role. 


\section{Some Examples from the Republic of Macedonia}

In the Republic of Macedonia, the universities still remain out of active involvement in entrepreneurship. Good example in promotion of entrepreneurship (Zarezankova-Potevska 2008: 690-697) is Mechanical Engineer Faculty at University "St Cyril and Methodius" in Skopje where are many centers for education and startup businesses including the business incubators for young engineers.

The Technical Faculty in Bitola has a Business Center with Business Incubator.

Nowadays "Entrepreneurship" as a subject is involved in the curriculum of secondary schools, at some universities' curriculums (FON (Faculty of Social Science), University Ss. Cyril and Methodius UKIM), including postgraduate studies at Economic Institute in Skopje.

\section{FON University Project “Factory of Knowledge" Case Study 1.}

"Factory of Knowledge" at FON University started as a project in 2010 and successfully is realized 5 years. It is a common project of FON University and Macedonian companies. It is applicable and educational project that include students and business communities and public institutions in realization of some practical problems and issues in the business strategy of the companies. The Project is designed as interdisciplinary. Students from every faculty are included in the teams and solved the problems from their fields of knowledge, like business strategy, business plan, marketing plan, planning, law problems, design etc. The teams of students, leading by the professors, go through some fazes of generating ideas, the review of ides, the development of the concept and testing, business analysis, technical feasibility, commercialization and budgeting.

The objectives of this Project are divided into two parts. The first part refers to the use of teams as one of the most important tools in the management and functioning of many companies. Through the Project the students implement theoretical knowledge and skills and practical solution of the problems in the economy. It means good relation between the high education and the business community in Macedonia. The second part of the aim of the Project is awards for the best teams like scholarship.

With this Project, the FON University showed the original idea for establishing the model of connection of universities and business communities that is very impressive and positive activity.

\section{Case Study 2.}

From September 2016, FON University is transformed in the University of the 3rd generation and is launched New Generation Program. 
It means new Management Board with foreign experts and professors whose primary task will be internationalization and new curriculums of double diplomas. The FON University will have very close cooperation and common diplomas with Universities from Valencia, Spain, from Italy, USA, UK and Nederland.

Under this Program, the FON University will performed:

- Reassessment of existing but improved study programs in English language;

- Additional accreditation of new study programs in the area of social, technical sciences and medical sciences;

- Accreditation of study programs for joint and double degrees with partner universities in the ranking of the top 500 according to the Shanghai ranking list of Universities;

- New accreditation in practical training programs will be conducted by the renowned global companies with their longstanding involvement of experts in the field of the study program is implemented or training directly in the workplace;

- New certificate programs and training courses for additional skills and competencies as part of informal education;

- Will be established business accelerators and technology parks to encourage R\&D.

These case studies show the intention of Faculty of Social Science (FON) University in Macedonia to be modern and attractive, close to the students who want to be well skilled and competent following new economic trends in the world.

Education system is one of the most important tools for developing entrepreneurship spirit and culture between the young generations at all. It means supporting creation, innovation in order to make more favored and pleasant environment for living and working, for better economic growth and prosperity.

\section{Business Ethics}

The contemporary business activities are characterized by the most modern methods of working and management, in which the particular importance is the creation of a favorable organizational culture, as a first step towards successful business results / performances in the short term, but especially in the long term. The era of globalization of economic flows, and the existence of strong competition in the international markets, needs high level of efficiency, devotion, loyalty, ethical behavior.

Under such conditions, in the processes in running the business, the role of the managers is the creation and maintenance of the good and harmonized human 
relations, stimulation and the motivation for efficient working, favorable business organization' climate and environment.

All activities is necessary to be subordinated to the basic goals of the organization, including moral attitude, good human relations, the favorable and pleasant business environment and culture of the organization. All these issues have strong influence on the organizational performance. In the organization, each individual has his own particular role and obligation to work professionally, conscientiously, ethically. In these business activities, in the adoption of important decisions for the future work of each organization, the role of the managerial team is the biggest. The managers should have a strong impact on other employees, stakeholders and other business partners with their personality, loyalty and moral. Therefore, the modern science of management includes the business ethic with particular attention.

Ethical behavior is necessary for successful development of each organization. Managers have to act ethically, to accept the high moral principles, and they have to accept the fact that they have social and public role or function, that they have social responsibility to their organization, but also to the environment in which living and working and society at all.

Each organization has own organizational culture that is characterized with fostering the moral norms in the relation with employees, managers, partners, the consumers, Current problems and barriers, temptations and dilemmas, should not be reason for changing the moral norms. They are eternal throughout the centuries. Therefore, modern societies accept business ethics as a very important issue in the life, in running business in economic, social and political activities. The training courses for business ethics are very often present in the big corporation as well as in the small ones. Ethics is included in the secondary schools, in the universities that have intention to be modern and high rated. So, these modern aspects of the education are present in the most developed countries as well as in the countries that have strong economic politics for grows and economic development.

Cultural differences, religion, tradition differences should not be barriers for economic activities of the different counties, regions and unions.

The education process, formal and informal, specially permanent education, have to accept all modern aspect of learning, new curriculums, including, entrepreneurship learning, principles of ethics, intercultural differences, new technology. All changes of education system should make capable and skilled people to create the entrepreneurial societies, prepared for appearance in the global markets.

For that reason, the governments and authorities in the EU and other countries, that are not high developed, have accepted a lot of documents, laws and regulative to be modern and creative, innovative and competitive in the processes of globalization in crude reality ${ }^{10}$.

\footnotetext{
10 Unfortunately, declared statements in adopted documents in Macedonia are not adequate realized, as a result of lack of knowledge for needs of development of entrepreneurship spirit and culture in the society for future prosperity of the country. For that reason there are no many active business centers, agencies and institutions for help creative people to make Macedonian society entrepreneurial, innovative and perspective one.
} 


\section{Conclusion}

For promotion and development of entrepreneurial spirit and culture in the society, as a step forward to built one entrepreneurial society, which mean supporting creativity and innovation to incentive people with ideas and programs, for overcome the poverty, for better life is necessary to create at first:

- Favorable business climate, that means legislation in purpose to running businesses without barriers;

- Realization of the Government' documents for entrepreneurship development on long term;

- Different incentives for startup businesses;

- List of financial instruments and institution for financial support of entrepreneurs, specially start up businesses;

- Appropriate institutions to support and promote entrepreneurship development, including both print and electronic media;

- Announcements of "Best Practice" in field of entrepreneurship development in purpose to raise the spirit and culture for entrepreneurship in the society;

- Modern educational system, especially universities, have to be in the function of development the entrepreneurial awareness and spirit including new curriculums in running business, ethics, cultural differences, new technology etc. and entrepreneurial knowledge;

- Acceptance and applying the LLL in purpose for raising the skills and competence of the people;

- Establishing institutional infrastructure for support SMEs and entrepreneurs;

- Support public-private partnership including involvement of the universities in industry projects;

- Networking as instruments for better communication and cooperation on national and international level.

All these activities and measures would be useful for improvement of awareness for entrepreneurship as a necessity tool for development the culture and entrepreneurial spirit at all citizens. It is useful entrepreneurship to be developed and to be style of thinking and life in function of better understanding the private sector. Universities should have very important task to educate young people for entrepreneurial activities and to prepare them to exist and survive on the global market. The adequate entrepreneurial culture may create a lot of jobs, to support them and exceed poverty and unemployment that are very present in the less developed countries in the world. Only entrepreneurial society is in possibility to create new jobs and better life for their citizens. The education process, formal and informal, specially permanent education, have to accept all modern aspect of learning, new curriculums, including, entrepreneurship learning, principles of 
ethics, intercultural differences, new technology. All changes of education system should make capable and skilled people to create the entrepreneurial societies, prepared for appearance in the global markets.

For that reason, the education system should play significant role. It depends on all relevant factors in the society.

\section{References}

Porter E. M. (1990) The Competitive Advantage of Nations, New York, Free Press.

Wisema H. (2009) Towards the Third Generation University - Managing, the university in transition, Rotterdam, Edward Elgar Publishing.

www.fon.edu.mk

Zarezankova Potevska M. (2008) The Role of the Macedonian Universities in Raising the Awareness of Development of Entrepreneurial Spirit, culture and Support the Cooperation with Industry and Economy, Skopje, Proceedings of the International Conference for Entrepreneurship, Innovation and Regional Development, 8th-11th May 2008, Skopje / Ohrid.

Zarezankova-Potevska M., Solymossy E. (2013) Entrepreneurship, Edited by "2nd $\mathrm{Au}-$ gust", Skopje.

Zarezankova-Potevska M., Taneva-Vesoska A. (2012) Business Communication and Ethics, Edited by “2-ri August”, Skopje. 